\title{
NEW TRIAL IN PRESENT PRACTICE
}

\author{
WILLIAM RENWICK RIDDELL \\ Supreme Court of Ontario
}

In the former article, ${ }^{1}$ we discussed the practice in new trials at the common law in England, and pointed out that the trial courts were inferior courts whose judges derived their authority from royal commissions and that they had no power to grant a new trial.

In the present article it is proposed to discuss the practice in new trials as it at present exists on both sides of the Atlantic in the Englishspeaking world which bases its jurisprudence on the English common law. ${ }^{2}$

\section{IN ENGLAND-CIVIL CASES}

The greatest change in English courts was effected by The Supreme Court of Judicature Act of $1873 .^{3}$ This far-reaching act united and consolidated all the superior courts of England into "one Supreme Court of Judicature in England" (sec. 3). This supreme court was to consist of two permanent divisions, one of which, "Her Majesty's High Court of Justice," was to have original jurisdiction with certain appellate jurisdiction from inferior courts; the other, "Her Majesty's Court of Appeal," appellate jurisdiction with certain original jurisdiction (sec. 4). The High Court was vested (inter alia) with all the jurisdiction which was or could be exercised by "the courts created by Commissions of Assize, ${ }^{4}$ of Oyer and Terminer and of Gaol Delivery, or any of such commissions" (sec. I6 [eleven]).

But this did not abolish the Court of Commissioners. Commissions still continue to be issued (sec. 29), and the only change that was

\footnotetext{
'New Trial at the Common Law (November, IgI6) 26 Yale LAw JouRNaL 49.

"This will exclude from consideration Quebec and Louisiana, etc., as well as Scotland and some of the small British Isles.

${ }^{3} 36$ \& 37 Vic. Ch. 66 . Sec. 2 of this act providing that (with a few exceptions) the act should come into operation on November $2 \mathrm{~d}$, 1874 , was repealed by the act of $1874,37 \& 38 \mathrm{Vic}$. Ch. 83 , which by sec. 2 directed that the act of 1873 should come into force on November Ist, 1875 .

-We have seen (26 YALE LAW JourNal 49, 5I) that at the common law, the commissioners usually had five commissions: I. Assize. 2. Nisi Prius. 3. Oyer and Terminer. 4. General Gaol Delivery, and 5. The Peace. The commission of Assize was directed to the judges and the clerk of assize to take assizes and do right upon writs of assize brought before them by such as were wrongfully thrust out of their possessions; these writs and the original and substituted practice on them are explained in $3 \mathrm{Bl}$. Comm. I84 et seq. When ejectment took the place of these writs, reducing such actions to trial at Nisi Prius, the commission of Assize became obsolete and the only civil commission issued was (properly speaking) that of Nisi Prius: nevertheless the term "Assizes" was retained and the commission was called a "commission of Assize."
} 
made was by making the Court of Commissioners part of the High Court; certiorari did not lie to it, but when it was desired to bring up a record in a criminal case, an order was made to bring the record from one part of the High Court, the Court of the Commissioners, to another, e. g., the Queen's Bench Division. ${ }^{5}$ No additional powers were given to the trial judge; $;^{6}$ applications for a new trial must still be made to the "court above." Of the five divisions into which the High Court was divided, three were common-law divisions: the Queen's Bench, the Common Pleas and the Exchequer Divisions-in all cases in any of these divisions, whether the case was tried with or without a jury, an application for a new trial was made to the divisional court "in term" for an order to show cause why a new trial should not be directed, quite the same as the rule nisi in the former practice; $;^{7}$ an appeal lay to the Court of Appeal. In 1876 a rule of court directed the application to be made to the Court of Appeal if the case was tried without a jury.

When the common-law divisions were consolidated into one, the Queen's Bench Division, in $1880,{ }^{8}$ the new rules substituted a simple notice of motion for an order nisi and changed the form in some instances-where the trial was by a judge without a jury, the application must be by appeal to the Court of Appeal, where with a jury in the Probate, Divorce and Admiralty Division to a divisional court of that division and in every other case to a divisional court of the Queen's Bench Division. ${ }^{\circ}$ Moreover, it was expressly provided that "no judge shall sit on the hearing of any motion for a new trial in any cause or matter tried with a jury before himself." 10 The Act of I890 ${ }^{11}$ directs that all motions for a new trial are to be made to the Court of Appeal "in any cause or matter in the High Court in which there has been a trial thereof, or of any issue therein with a jury." The effect of this enactment is to eliminate the divisional court; $;^{12}$

'See, per Lord Coleridge, C. J., in Queen v. Dudley and Stephens (I884) L. R. I4 Q. B. D. $273,280$.

-We shall see that from 1883 , the right of a trial judge to take part in the hearing of an application for a new trial in a case tried before him was taken away.

'In the Chancery Division, whose judges had not a Nisi Prius commission, the application for a "rehearing" was to the judge: the judge before whom the action was pending could order a new trial of an issue directed by himself. In the Probate, Divorce and Admiralty Division, the application was to the judge who tried the case.

B By Order in Council, December I6th, 1880, authorized by the Act of 1873 , sec. 32; this may be seen in Wilson, Judicature Acts (5th ed. London, r886) 45-48.

${ }^{\circ}$ Rules of $\mathrm{r883}$. Order XXXIX, r. I (R. 55I).

${ }^{10}$ Idem. Order XXXIX, r. 2 (R. 552).

II Supreme Court of Judicature Act of $1890,53 \& 54$ Vic. Ch. 44 , sec. I.

12 The language of Lord Justice Kay in Allcock v. Hall (C. A.) [189r] I Q. B. 444, 449. The present rule governing applications for new trials is Order 
applications in cases tried without a jury still go to the Court of Appeal.

\section{IN ENGLAND-CRIMINAL CASES}

We have seen that at the common law there was no power in any court to grant a new trial in cases of felony, and that while power was considered to exist in the Court of King's Bench to grant a new trial in cases of misdemeanor, the power was sparingly exercised,never when there was an acquittal except in certain quasi-civil cases, e. g., in Quo Warranto. ${ }^{13}$ In the previous article, no account was taken of the venire facias de novo juratores, which was not technically an order for a new trial, but which had substantially the same effectthis was awarded by the court (not the trial judge) where a jury was discharged without verdict, where a special verdict was insufficient and in a court of error in cases of mistrial or imperfect verdict.

None of these powers was affected in any way by the various judicature acts, but in I907 a very great change was effected by the Criminal Appeal Act of $1907 . .^{14}$ This act abolished writs of errors and all the jurisdiction and practice of the King's Bench Division (which had, under the judicature acts, succeeded to the position of the former Court of King's Bench) as to the grant of new trials in criminal cases, and substituted an appeal against a conviction to a Court of Criminal Appeal on questions of law or (by leave) on questions of fact, or of mixed law and fact, or as to the legality or propriety of the sentence imposed. But no power was given to grant a new trial; and however regrettable the result-an appeal succeeding even on the ground of misdirection to the jury-the conviction is quashed and the accused goes free. ${ }^{15}$

In the British Colonies the course of amendment has been not dissimilar to that of England-I trace that in Ontario (Upper Canada) only.

XXXIX, r. I (R. S. C. August, rgI3)-all applications must he made to the Court of Appeal whether the case is tried with or without a jury.

${ }^{23} 26$ Yale LAw Journal 49, 58.

"Is07) 7 Edw. VII, Ch. 23.

${ }^{15}$ In Rex v. Dyson (Ct. Cr. App.) [1908] 2 K. B. 454, 458, Lord Alverstone, C. J., said :

"It is to be regretted the Legislature when passing the Criminal Appeal Act did not empower the Court to order a new trial, for the present is a case in which it is eminently desirable that such a power should exist. But they did not think fit to do so, and we have no choice but to allow the appeal."

This was a case of misdirection as was the later case of Rex v. Ahlers (IgI4) 24 Cox. C. C. 623 , where a German-born British subject escaped the punishment of high treason.

I have not said anything of the practice under The Crown Cases Act of 1848 , II \& I2 Vic. Ch. 78, still in force in Ireland, never in force in Scotland, and repealed as to England by the Criminal Appeal Act of 1907. That act authorized 


\section{IN UPPER CANADA (ONTARIO)-CIVIL CASES}

Upper Canada in I792 began its provincial career with its immense territory divided into four districts. In each of these districts there was a Court of Common Pleas with full civil but no criminal jurisdiction. This condition lasted but a short time; but while it lasted, applications for a new trial were made to the judges of the Court of Common Pleas of the district. These judges presided at the trial of actions by virtue of their office and did not have commissions of Assize, etc. The law administered was Canadian, i. e., French-Canadian, although trial by jury was allowed. ${ }^{16}$ In I794 these four Courts of Common Pleas were abolished and a Court of King's Bench created $^{17}$ with the same jurisdiction, civil and criminal, as the Courts of King's Bench, Common Pleas and Exchequer (on the common-law side) in England. This Court of King's Bench has been continued into and is now (with other courts consolidated with it) the Supreme Court of Ontario..

With the institution of the Court of King's Bench, the English system of Nisi Prius and Assize Courts was introduced. Before this time, as the Courts of Common Pleas had no criminal jurisdiction, commissions of Oyer and Terminer and General Gaol Delivery had been issued for each district, ${ }^{18}$ and this practice continued after the Act of I794.

The act provided that commissions of Assize and Nisi Prius should be issued into each district once or twice yearly as was thought proper for the trial of issues in vacation between terms; and power was given to issue special commissions to try special offenders, $i$. $e$., special commissions of Oyer and Terminer.

the trial judge in case of a conviction for crime to reserve any question of law which might have arisen on the trial for the consideration of the justices of either bench or the barons of the Exchequer. These, a Court for Crown Cases Reserved, had large powers but not the power to grant a new trial.

${ }^{18}$ A full description of these curious courts will be found in a series of articles, The Early Courts of the Province (I915) 35 Can. Law TIMEs, a paper read before the Royal Society of Canada, May 28th, I913, Practice of Court of Common Pleas of the District of Hesse, 7 Transactions R. S. Can. (3d Ser. I913) 43 et seq., and an Address before the Michigan Bar Association, June, 1915, The First Judge at Detroit and his Court-all by myself.

${ }^{17}$ By 34 Geo. III, Ch. 2 (U. C.).

${ }^{18}$ For example, the first chief justice of Upper Canada, William Osgoode, never sat in the Court of King's Bench, as he had left the province to become chief justice of Lower Canada before the Court of King's Bench in Upper Canada had been organized; but he sat several times in criminal courts under commissions of Oyer and Terminer and General Gaol Delivery. So, too, William Dummer Powell, afterwards chief justice of Upper Canada, when he was still first judge at Detroit (then British) in the Court of Common Pleas for the district of Hesse (afterwards the Western District) is known to have sat at criminal courts under such commissions (I have a photostat copy of one before me as I wrife). 
It was not until $1855^{19}$ that commissions of Assize and Nisi Prius, Oyer and Terminer and General Gaol Delivery weré rendered unnecessary, Parliament providing that such courts should be held at such times as the judges of the courts of common law (by this time a Court of Common Pleas had been formed ${ }^{20}$ with the same powers as the Court of Queen's Bench) should appoint. The judges of the courts of common law were to sit in these courts of Assize and Nisi Prius, Oyer and Terminer and General Gaol Delivery with the same powers as though they had commissions as formerly.

By the Common Law Procedure Act of $185^{61}$ the times of the sittings of these trial courts were to be fixed by the judges, and the judges might sit with or without commissions as the Governor (i. e., the Ministry) should deem best. ${ }^{22}$ In 1874 the Administration of Justice Act ${ }^{23}$ provided for Courts of Assize and Nisi Prius to be held without commissions and that any judge or Queen's Counsel presiding at any court of Assize, Nisi Prius, Oyer and Terminer and General Gaol Delivery should have all the powers which he would have had under commissions under the former practice.

It may be said that since the act of 1856 we have not had in Ontario commissions for trial courts, except special commissions of Oyer and Terminer, etc., the power to issue which is still continued and has been exercised.

When in I88I, the two common-law courts and the court of chancery were united in one court, the Supreme Court of Judicature for Ontario, ${ }^{24}$ there was an express provision for commissions of Assize, etc., issuing by proper authority, but the existing condition was not interfered with that the ordinary trial courts should be held with or without a commission as the Governor (i.e., the Ministry) should deem best. At the present time the days upon which such courts are to begin their sittings, and the judge who is to preside over each, are fixed by the judges of the High Court Division of the Supreme Court and no commission issued. But no power was ever given to a judge presiding at a trial court to grant a new trial: when the Courts of Queen's (King's) Bench and Common Pleas were separate and distinct courts, the application for a new trial must be made in term to the court from which process issued. When by the Judicature Act of I88I the courts were amalgamated, there was still

${ }^{29}$ I8 Vic. Ch. 92 , sec. 43 (Can.).

${ }^{20} \mathrm{By} 12$ Vic. Ch. 63 (Can.) in 1849.

${ }^{21}$ Ig \& 20 Vic. Ch. 43 , secs. 152 , I53 (Can.).

$=$ The legislation is continued and slightly amended in $1857,20 \mathrm{Vic}$. Ch. 57 , sec. 30 ; I859, C. S. U. C. Ch. II, secs. $1,2,3$; I866, 29 \& 30 Vic. Ch. 40, sec. 3 ; all statutes of the province of Canada-after Confederation the Province of Ontario passed (1873) Ch. 8, sec. 52 (Ont.).

" (1874) 37 Vic. Ch. 7 (Ont).

${ }^{24} \mathrm{By}$ The Ontario Judicature Act of $\mathrm{I} 88 \mathrm{r}, 44$ Vic. Ch. 5 (Ont.). 
as in England a division into divisional courts corresponding to the former separate courts; and for a time the application must be made to the divisional court of the division to which the action was instituted. ${ }^{25}$ Such was the case where an action was tried by a jury: if the action was tried by a judge without a jury, the application was to the Court of Appeal. Later amendments permitted the application even in cases tried without a jury to be made to the divisional court if desired. ${ }^{28}$ When actions ceased to be assigned to any division ${ }^{27}$ and all writs were styled simply "In the High Court of Justice," the motion for a new trial was heard by any divisional court or the Court of Appeal.

All divisional courts of the High Court were abolished by an act ${ }^{28}$ coming into force January Ist, x913, and now all applications for a new trial must be made to the Appellate Division of the Supreme Court of Ontario, corresponding to the former Court of Appeal. It should be said that by rule in Ontario, as in some other provinces, the trial judge may grant a new trial where a party does not appear and judgment has gone against him.

It is not necessary to trace the history of the practice of new trial in the other Provinces; in none of them has the trial judge any power in that regard and the application must be made to the "court above."

\footnotetext{
${ }^{25}$ Before the Judicature Act of I88I; common-law actions were begun by writs which were issued from the two common-law courts alternately (in order to equalize the work of the two courts, each of which had the same jurisdiction, practice, etc.): proceedings in chancery were begun by bill of complaint. The Judicature Act abolished the bill of complaint and directed that all actions (now including suits) should begin by writ of summons, but that the writ should be styled in one or other division-Queen's Bench Division, Common Pleas Division or Chancery Division, secs. 23, 25. Writs in the Queen's Bench and Common Pleas Division were to be issued alternately, $R$. 2I. The action was accordingly styled in some division and application for a new trial was made to the divisional court (generally of three but sometimes only two judges) of that division, R. 307. The application was by way of order nisi corresponding to the former rule nisi-in the Court of Appeal, a simple notice was given.

${ }^{20}$ When the rules were amended in 1888 (in force March Ist, I888) it was directed that writs should issue alternately from the Queen's Bench, Chancery and Common Pleas Divisions ( $R, 226$ ); and that after a trial by a judge without a jury, the application for a new trial might be made either to the divisional court or the Court of Appeal.

${ }^{27}$ By rules coming into force September Ist, I897: R. I27, Forms I, 2, 3 .

${ }^{2}$ The statute $3 \& 4$ Geo. V, Ch. I9-The Judicature Act-brought into force January Ist, rgr3, by proclamation. This forms one superior court, the Supreme Court of Ontario, with two divisions, the Appellate Division and the High Court Division-the latter being the trial division. I may add that while there has never been any express prohibition against the trial judge sitting in a court upon an application for a new trial in a case tried before him, it has never been done since the abolition of the practice of issuing writs out of a particular division.
} 
IN UPPER CANADA (ONTARIO)-CRIMINAI CASES

In Upper Canada the English practice was followed: there was no new trial in felonies, nor in misdemeanors in cases of acquittal except in certain quasi-civil cases. ${ }^{29}$ In $185 \mathrm{I}$ an act was passed $^{30}$ which enabled the trial judge in case of a conviction to reserve a case for the consideration of either common-law court, but it was held that this did not empower the court to grant a new trial. ${ }^{31}$

In 1857,32 Parliament enacted that a person convicted of a crime might

"apply for a new trial upon any point of law or question of fact in as ample a manner as any person may apply to the Superior Courts of Common Law for a new trial in a civil action" and "if the conviction be affirmed the person convicted may appeal to the Court of Error and Appeal."

If the conviction was in the Quarter Sessions, the application for a new trial must be made to that court and if the appeal should fail, a further appeal lay to a court of common law. In $1869,{ }^{33}$ all power was taken away from every court to grant a new trial. Thereafter the convicted person must rely upon a case reserved for one of the common-law courts; the appeal from the common-law courts to the Court of Error and Appeal was also taken away.

When the Criminal Code was enacted in I892,34 power was given on the refusal of the trial judge to reserve a case for the convict (with the leave of the attorney general given in writing) to move the Court of Appeal for such a case: when a reserved case should come before the Court of Appeal, that court might order a new trial or make such order as it should deem proper. If the judges of the Court of Appeal were unanimous, their decision was to be final; if not, an appeal might be taken to the Supreme Court of Canada.

Some changes have been made in the practice: at the present time the "Court of Appeal" is in Ontario the Appellate Division of the

\footnotetext{
${ }^{20}$ I mention only Upper Canada, but the English criminal law was in force in Lower Canada from 1763 ; and the laws of the two provinces in criminal matters have always been practically the same.

"I4 \& I5 Vic. Ch. I3 (Can.) passed by the Parliament of United Canada-the two Provinces of Upper and Lower Canada became one Province of Canada by the Union Act of $1840,3 \& 4$ Vic. Ch. 35 (Imp.) coming into effect February Ioth, I84I, and so continued until the formation of the Dominion of Canada by The British North America Act of 1867,30 \& 31 Vic. Ch. 3 (Imp.) coming into effect July Ist, 1867.

${ }^{21}$ Reg. v. Baby (1854) I2 U. C. Q. B. 346: the act was much like the English Act of r848 referred to above which also was held not to enable a new trial to be granted.

20 Vic..Ch. 6r, secs. I, 2, 4 (Can.) : Cf. C. S. U. C. Ch. II3, secs. I, 3, 6, 7.

« By 32 \& 33 Vic. Ch. 29, sec. 80 (Dom.).

st (I\&92) 55 \& 56 Vic. Ch. 29 (Dom.), The Criminal Code of I8g2.
} 
Supreme Court of Ontario, and a convict may move without the leave of the attorney general; if he moves on the ground of weight of evidence, however, he must obtain the leave of the trial judge. ${ }^{35}$

\section{IN THE UNITED STATES}

The common law of England became the common law of the United States as it had been the common law of the thirteen colonies: while there is no report of any decision in the colonies before the Revolution granting a new trial, there is no doubt that the courts of general jurisdiction exercised the power of granting new trials in proper cases.

The Nisi Prius system was not in vogue and the trial judge (at least in most cases) sat as the court and not as a mere commissioner; and he it was to whom the application for a new trial was made. In Massachusetts the Nisi Prius system was adopted in 1803-4 with the necessary consequence ${ }^{30}$ but in most cases the trial judge was always "the court."

In some of the states the losing party could have a new trial as of right by merely claiming an appeal as in Massachusetts, ${ }^{37}$ Connecticut ${ }^{38}$ and some other states.

${ }^{s}$ R. S. Can. 1906, Ch. 146, The Criminal Code, secs. 1013, ro14 (proceedings in error prohibited), 1015, 1016, 1018, 1019, I021, 1024. Sec. I022 gives power to the minister of justice to order a new trial if he "entertains a doubt whether such person ought to have been convicted." This power has been exercised once and (I think) only once. Practice in criminal cases, like criminal law in general, being by The British North America Act (the written constitution of Canada) entrusted to the Dominion, criminal practice is now uniform throughout the Dominion.

${ }^{30}$ See Miller v. Baker (1838, Mass.) 20 Pick. 285, 288, per Shaw, C. J., delivering the judgment of the court.

${ }^{87}$ See U. S. v. 1363 Bags of Merchandise (1863, U. S. D. C. Mass.) 2 Sprague, 85, 86 (25 Montely Law Rep. 600), per Sprague, J., who adds :

"If the second verdict was the same as the first, it was conclusive unless the court, in its discretion, should see fit to set it aside. If the result of the second trial was different from that of the first, the losing party had a right, by a process of review, to have another trial. The losing party in the third trial, having had two verdicts against him, was concluded thereby, unless the court should grant him a new trial. By this system it was not thought safe to rely upon the finding of a single jury. A party could claim a re-trial as matter of right until two verdicts had gone against him, and even then the court had the power to grant another trial if in their discretion they should deem it proper. This system commenced at an early period, and was in operation for a long time. It continued for some years after Maine became a separate State. I had then some agency in bringing about a change."

"O fortuntatos nimium sua si bona norint advocati."

${ }^{3}$ Bartholomew v. Clark (I8I6) I Conn. 472, 473, per N. Smith (arguendo) ".. . which was granted of course to the unsuccessful party, until there had been two verdicts the same way." The reporter, Thomas Day, adds a note: "This practice still exists, to a certain degree, in some of the New-England states." It certainly did exist in Massachusetts, as Maine did not become a separate state till 1820 , - and we have seen that the practice was in vogue in Massachusetts at that time. 
But the rule in granting new trials became much the same as in England in respect of grounds for such a proceeding. At the present time in practically every state of the Union, the trial judge has power to grant a new trial.39 New Jersey is an exception: there the practice is to apply to the trial judge for a rule to show cause why the verdict should not be set aside and a new trial ordered (the common-law rule nisi); the rule is then argued before the full court (the trial judge being a member) in term. This is substantially the common-law system, except that in New Jersey it is the trial judge and not the court en banc who grants the rule to show cause.

In most of the states it is considered that the power of the trial judge to grant a new trial is purely statutory: but in some it is considered that the right is "inherent in the trial court" (Alabama), that the right is a common-law right (Massachusetts, Michigan, Minnesota), but regulated and modified by statute (Missouri, New York, North Carolina, Wisconsin). Connecticut thinks it an affirmance of the common law; Indiana can trace her statutory power back to I852; Maine derived her jurisprudence from Massachusetts but now it seems to be wholly statutory. ${ }^{40}$

The decision of the trial judge is final in Delaware, Maine and - New Mexico; where a new trial is granted there is no appeal in California (though the order is reviewable on an appeal from the judgment), Colorado, Indiana, Michigan, Minnesota, Missouri (in criminal cases); in North Carolina an appeal from the trial judge's decision is allowed only when a new trial is granted on the ground of error committed in the trial, while in South Carolina the supreme court cannot review the facts and can grant a new trial only where a question of law is involved on which the trial judge has made an erroneous finding.

In the other states named in note 39 , there is an appeal from the decision of the trial judge.

I have not considered the case of inferior courts: in all instances any power they possess to grant a new trial is statutory; nor have $I$ considered the venire de novo employed where the verdict was defective, etc.-in some states, e. g., Indiana, that is considered not affected by legislation.

\footnotetext{
${ }^{30}$ I have to thank the chief justices of the following states for their ready and courteous answers to my enquiries: Alabama, Arkansas, California, Colorado, Connecticut, Delaware, Florida, Indiana, Iowa, Kansas, Louisiana, Maine, Massachusetts, Michigan, Minnesota, Missouri, Montana, Nebraska, Nevada, New Jersey, New Mexico, New York, North Carolina, Oklahoma, Oregon, South Carolina, Wisconsin, Wyoming.

I have not made an independent examination but have contented myself with the information these eminent gentlemen have given me either expressly or by reference to authority.

"see Averill v. Rooney (I87I) 59 Me. 580, Laws of I872, Ch. 83: R. S. (I903) Ch. 84 , sec. 54
} 